Kwalitatief onderzoek 


\title{
Kwalitatief onderzoek
}

Praktische methoden voor de medische praktijk

\author{
P.L.B.J.Lucassen
}

T.C. olde Hartman

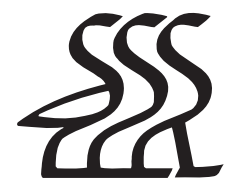

Bohn Stafleu van Loghum

Houten 2007 
(C) Bohn Stafleu van Loghum, 2007

Alle rechten voorbehouden. Niets uit deze uitgave mag worden verveelvoudigd, opgeslagen in een geautomatiseerd gegevensbestand, of openbaar gemaakt, in enige vorm of op enige wijze, hetzij elektronisch, mechanisch, door fotokopieën of opnamen, hetzij op enige andere manier, zonder voorafgaande schriftelijke toestemming van de uitgever.

Voor zover het maken van kopieën uit deze uitgave is toegestaan op grond van artikel 16b Auteurswet 1912 $\mathrm{j}^{\mathrm{o}}$ het Besluit van 20 juni 1974, Stb. 351, zoals gewijzigd bij het Besluit van 23 augustus 1985, Stb. 471 en artikel 17 Auteurswet 1912, dient men de daarvoor wettelijk verschuldigde vergoedingen te voldoen aan de Stichting Reprorecht (Postbus 3051, 2130 KB Hoofddorp). Voor het overnemen van (een) gedeelte(n) uit deze uitgave in bloemlezingen, readers en andere compilatiewerken (artikel 16 Auteurswet 1912) dient men zich tot de uitgever te wenden.

Samensteller(s) en uitgever zijn zich volledig bewust van hun taak een zo betrouwbaar mogelijke uitgave te verzorgen. Niettemin kunnen zij geen aansprakelijkheid aanvaarden voor drukfouten en andere onjuistheden die eventueel in deze uitgave voorkomen.

ISBN 9789031349982

NUR 870

Ontwerp omslag: Fredrik Helfrich, Deventer

Ontwerp binnenwerk: TEFF Typography

Automatische opmaak: Alfabase, Alphen aan den Rijn

Bohn Stafleu van Loghum

Het Spoor 2

Postbus 246

3990 GA Houten

www.bsl.nl
Distributeur in België: Standaard Uitgeverij

Mechelsesteenweg 203

2018 Antwerpen

www.standaarduitgeverij.be 


\section{Inhoud}

Voorwoord

Nieuwsgierige dokters kijken dóór een telraam

1 Kwalitatief onderzoek: nuttig, onmisbaar en uitdagend

1.1 Inleiding 5

1.2 Wat is kwalitatief onderzoek?

1.3 Kwalitatief onderzoek en ondersteuning van de dagelijkse praktijk

1.4 De open methodologie van kwalitatief onderzoek

1.5 Een inzicht van de verscheidenheid aan technieken van kwalitatief onderzoek $\quad 10$

1.6 Tot slot 11

Literatuur

2 Waarnemingsmethoden in kwalitatief onderzoek 13

$2.1 \quad$ Inleiding 13

2.2 Kenmerken van kwalitatief onderzoek 14

2.3 Methodologische criteria 14

Geldigheid 15

Betrouwbaarheid 18

2.4 De gevalsstudie en longitudinaal onderzoek 22

2.5 Voorbeeld van goed kwalitatief onderzoek 23

Literatuur 24

3 Systematiek en toepassing van de kwalitatieve survey 27

$\begin{array}{lll}3.1 & \text { Inleiding } & 27\end{array}$

3.2 De kwalitatieve survey 28

3.3 De kwalitatieve en de statistische survey in acht stappen 
3.4 De kwalitatieve survey in vergelijking tot andere vormen van kwalitatief onderzoek 38

3.5 Tot slot: de kwaliteit 39

Literatuur 40

4 Het halfopen interview als onderzoeksmethode 43

4.1 Inleiding 43

4.2 Het halfopen interview 43

4.3 Een praktisch voorbeeld 45

4.4 Interviewen met behulp van een topiclijst 47

4.5 Conclusie 49

Literatuur $\quad 50$

5 Exploreren met focusgroepgesprekken: de 'stem' van de groep onder de loep $\quad 53$

5.1 Inleiding 53

5.2 Wat zijn focusgroepen? 53

5.3 Waarom en wanneer is focusgroeponderzoek geïndiceerd? 54

5.4 De praktische uitvoering van een focusgroep 56

Aantal focusgroepen, samenstelling, selectie van deelnemers 56

Rol moderator, observator 58

Een script voor een focusgroepsdiscussie $\quad 59$

Praktische organisatie van het gesprek 61

5.5 Randvoorwaarden voor focusgroeponderzoek 61

5.6 Gegevensverwerking en rapportering 62

5.7 Valkuilen 62

5.8 Besluit 63

Literatuur 63

6 Participeren in ziekte en zorg: meer over kwalitatief onderzoek

6.1 Inleiding 65

6.2 Voordelen van participatie 66

6.3 Beperkingen van participatie 66

6.4 Participeren als hulpverlener, betrokkene of zieke? 67

$\begin{array}{ll}\text { Als hulpverlener } & 67\end{array}$

Als betrokkene $\quad 69$

Als zieke 69

6.5 Conclusie: permanente receptiviteit 72

$\begin{array}{ll}\text { Literatuur } & 72\end{array}$

7 Conversatieanalyse: orde in de details 75

$\begin{array}{lll}7.1 & \text { Inleiding } & 75\end{array}$

$\begin{array}{lll}7.2 & \text { Ontwikkeling } & 75\end{array}$ 
$\begin{array}{lll}7.3 & \text { Kernbegrippen } & 76\end{array}$

$\begin{array}{lll}7.4 & \text { Werkwijze } & 77\end{array}$

$\begin{array}{lll}7.5 & \text { Na de dood van Harvey Sacks } & 78\end{array}$

$\begin{array}{lll}7.6 & \text { Taal en CA } & 79\end{array}$

$\begin{array}{lll}7.7 & \text { Audio of video } & 79\end{array}$

7.8 Institutionele interactie 80

7.9 CA en andere agenda's $\quad 80$

7.10 CA en het medische veld 81

$\begin{array}{lll}7.11 & \text { Ten slotte } & 83\end{array}$

Literatuur 83

8 Analyse van kwalitatief onderzoeksmateriaal 85

8.1 Inleiding 85

8.2 Een schets van de kwalitatieve analyse 86

8.3 Gefaseerde werkwijze 86

8.4 Tekst als materiaal 88

8.5 De interpreterende analyse: open coderen 89

8.6 Gericht coderen en vergelijkende analyse 90

8.7 Profielkaarten, overzichten en tabellen 91

8.8 Rapportage 92

8.9 De rol van de computer 92

8.10 Aandachtspunten bij het lezen van een analyse $\quad 92$

8.11 Conclusie 94

Literatuur $\quad 95$

9 Computerondersteuning in de kwalitatieve analyse 97

9.1 Introductie 97

9.2 Functies van computerprogramma's 98

Transcriptie en opslag van de gegevens 98

Verkenning van het materiaal 99

Ordening van het materiaal $\quad 99$

Terughalen van en zoeken in het materiaal $\quad 100$

Aanbrengen van veranderingen 100

Ondersteuning bij speciale vormen van analyse $\quad 101$

Voorbereiden voor aanvullende analyse $\quad 101$

Bijhouden van het analyseproces 101

9.3 Een voorbeeld: Kwalitan 102

Analyseren met codes $\quad 103$

Analyseren met woorden $\quad 105$

Analyseren van concepten $\quad 105$

Werken met memo's 106

Wat Kwalitan nog meer te bieden heeft 107

9.4 Toepassing en valkuilen 108

$\begin{array}{lll}9.5 \text { Tot slot } & 109\end{array}$

Literatuur $\quad 110$

Websites van de genoemde software $\quad 110$ 
10 Waardering van kwalitatief onderzoek

10.1 Inleiding

10.2 Betrouwbaarheid en validiteit als maten voor

objectiviteit

Betrouwbaarheid

Validiteit

10.3 Methodologische kwaliteit: hoe herken je het?

10.4 Tot slot: de waarde van kwalitatief onderzoek voor de praktijk

Literatuur

11 Meta-etnografie en de synthese van kwalitatief onderzoek

11.1 Inleiding

Terminologie

Kwantitatief onderzoek

Kwalitatief onderzoek

11.3 De synthese van kwantitatieve evidence

11.4 De synthese van kwalitatieve evidence

11.5 Meta-etnografie

11.6 De methode van Noblit en Hare

11.7 Aanpassingen en toepassingen van de meta-etnografie

11.8 Valkuilen

11.9 Een praktisch voorbeeld van meta-etnografie

11.10 Kwalitatief onderzoek in systematische reviews van RCT's

11.11 Besluit

Literatuur

12 Multimethodenonderzoek

12.1 Inleiding

12.2 Verschillen kwantitatief en kwalitatief onderzoek

12.3 Onderzoek met gemengde methoden

12.4 Designs in het multimethodenonderzoek

Voorbereidend en verwerkend

multimethodenonderzoek

Parallel multimethodenonderzoek

Opeenvolgend multimethodenonderzoek

Geïntegreerd multimethodenonderzoek

12.5 Validiteit en kwaliteit

12.6 Obstakels

12.7 Conclusie 


\section{Voorwoord}

\section{Nieuwsgierige dokters kijken dóór een telraam}

There are doctors who are craftsmen, who are politicians, who are laboratory researchers, who are ministers of mercy, who are businessman, who are hypnotist, etc. But there are also doctors who [...] want to experience all that is possible, who are driven by curiosity. But 'curiosity' is too small a word and 'the spirit of enquiry' is too institutionalized. They are driven by the need to know. The patient is their material... John Berger, A fortunate man

Berger beschrijft in A fortunate man - een helaas bijna vergeten boekje - het leven van John Sassal, huisarts in de jaren zestig op het platteland van Engeland. In veertig jaar is er blijkbaar niet veel veranderd: er zijn nog steeds dokters die goede ambachtslieden zijn, dokters die keurig protocollen uitvoeren, dokters die onderzoek doen, maar een beetje buiten de werkelijkheid staan, dokters die hun zaken goed runnen en alle varianten die je met deze typeringen verder kunt bedenken. Al die dokters doen hun werk vaak wel naar behoren, maar ze halen er voor hun patiënten noch voor zichzelf uit wat erin zit.

Gelukkig zijn er ook nu nog veel nieuwsgierige dokters zoals Sassal. Dokters die zich dagelijks in de praktijk afvragen waarom iets nu is zoals het is, of waarom mevrouw Violet zo vaak bij de dokter komt. Soms vragen die dokters zich af welke pil je waarvoor moet geven, maar hun vak houdt daarmee niet op. Dan zou het snel saai worden. De ontrafeling van het theater van de praktijk, dat is de uitdaging van dokters en onderzoekers.

Het heeft even geduurd voordat vermetele geesten de sacrosancte status van de randomized controlled trial ter discussie stelden. Evidence-based werken is meer dan het slaafs volgen van resultaten uit klinische trials waarin onderzoekers in verre landen patiënten hadden ingesloten die nooit op die van $\mathrm{u}$ of van mij leken. Bovendien gebruiken onderzoekers ingewikkelde vragenlijsten of biochemische parameters, waarmee ik patiënten niet wil of kan lastigvallen. Een Rст is prima als het om simpele vragen gaat: moet je antibiotica geven bij een middenoorontsteking en hoe snel is het dan over? Maar in de huisartsgeneeskunde gaat het vaak om veel complexere problemen: 
Wat is de beste manier om ouders ervan te overtuigen dat antibiotica niet nodig zijn bij Kareltje Bavink's zere oor? Hoe zorg ik ervoor dat de dementerende mijnheer Koekenbakker's nachts niet zo onrustig is dat hij zijn vrouw en de buren overstuur maakt? Welk advies moet ik mevrouw Hoyer geven die artrose heeft en bijna niet kan lopen, maar moet bewegen vanwege haar diabetes? Wat vinden mevrouw Ploeger en meneer Bekker nu belangrijk bij de zorg voor hun oude vader, meneer Grönloh?

Al die vragen zijn heel wat lastiger in een strak Rст-format te persen dan een simpele geneesmiddelenvraag.

En wellicht hoeft dat ook niet. De auteurs in dit boek laten zien dat er andere manieren zijn om allerlei aspecten van de werkelijkheid in kaart te brengen.

Huisartsen praten met patiënten - en ze zouden vooral moeten luisteren vaardigheden die weinig kwantitatieve aspecten hebben. Kwantitatief onderzoek, hoe belangrijk ook, past misschien wel minder goed bij de natuurlijke ‘verhaallijnen' van onze patiënten. Praten met en luisteren naar patiënten kunnen volgens de auteurs van dit boek een alternatief zijn voor het rekenen en meten in kwantitatief onderzoek. Kwalitatief onderzoek is echter meer dan een beetje vrijblijvend met mensen praten, het is een echte methodologie. Kwalitatieve onderzoeksmethoden zijn oud, ouder zelfs dan de RCT, en hebben de afgelopen tien jaar een sterke ontwikkeling doorgemaakt. Onderzoekers kijken buiten hun eigen grenzen, naar etnografen, sociologen en psychologen. In die vakgebieden heeft kwalitatief onderzoek een hoge vlucht genomen.

Het wordt tijd dat huisartsen hun achterstand op het gebied van kwalitatief onderzoek inhalen. Kijken, luisteren en de goede vragen stellen, zijn immers kernvaardigheden van elke huisarts. Dat moeten we toch net zo goed kunnen als gedragswetenschappers of cultureel antropologen?

Dit boek kan helpen om onderzoek en werkelijkheid in een ander perspectief te zien. Vijf van de twaalf hoofdstukken verschenen tussen 2004 en 2006 in Huisarts en Wetenschap. Speciaal voor dit boek zijn er zeven praktische hoofdstukken geschreven over focusgroepen, kwalitatieve surveys, halfopen interviews, conversatieanalyse, computerprogramma's, meta-etnografie en de toverdoos waarin alles gecombineerd is, het multimethodenonderzoek. Kwalitatief onderzoek moet je leren en dit boekje helpt daarbij.

Als nieuwsgierige onderzoekers dan ook nog leren om observaties van het leven mooi en bondig op te schrijven, dan hebben gewone huisartsen en hun patiënten werkelijk iets aan deze spiegel van de werkelijkheid.

Maart 2007

Joost Zaat 


\section{Over de redactie}

Peter Lucassen is huisarts in Bakel en als senior onderzoeker verbonden aan de afdeling Huisartsgeneeskunde van het UMC St Radboud in Nijmegen. Hij was zes jaar lid van de redactie van Huisarts en Wetenschap. In zijn werk als senior onderzoeker houdt hij zich bezig met de bestudering van GGz-problematiek in de huisartspraktijk, waaronder onverklaarde lichamelijke klachten. De kwalitatieve onderzoeksmethode is een van de daarbij gebruikte middelen.

Tim olde Hartman is sinds twee jaar huisarts. Naast zijn werk als praktiserend huisarts in Oosterhout (gemeente Nijmegen) is hij verbonden aan de afdeling Huisartsgeneeskunde van het UMC St Radboud in Nijmegen, waar hij werkt aan zijn promotieonderzoek naar onverklaarde lichamelijke klachten in de huisartspraktijk. Hij was twee jaar junior lid van de redactie van Huisarts en Wetenschap. 